\title{
Process Characteristics of a Commercial-scale Oxygen Blast Furnace Process with Shaft Gas Injection
}

\author{
Yotaro OHNO, ${ }^{1)}$ Masahiro MATSUURA, ${ }^{2)}$ Hiroyuki MITSUFUJI ${ }^{3)}$ and Takeshi FURUKAWA ${ }^{2)}$
}

Research and Development Division, NKK Corporation,

1) Planning and Coordination Dept., Maru-no-uchi, Chiyoda-ku, Tokyo, 100 Japan. $\quad 2$ 2) Steel Research Center, Minamiwatarida-cho, Kawasaki-ku, Kawasaki, Kanagawa-ken, 210 Japan. $\quad 3)$ Steel Division, Fukuyama Works, NKK Corporation, Kokan-cho, Fukuyama, Hiroshima-ken, 721 Japan.

(Received on March 17, 1992; accepted in final form on March 19, 1992)

\begin{abstract}
A new oxygen blast furnace process, which is characterized by the injection of preheating gas into the shaft, was developed. For the development of the process, operation tests using an experimental blast furnace were carried out, and proved this process to be applicable as an ironmaking process. Mathematical model simulations were also carried out and the process characteristics were clarified on a commercial scale, in comparison with those of a conventional hot blast furnace process.

Through the analysis of the experimental blast furnace operation and the mathematical model simulations, this process was found to have the following characteristics;
\end{abstract}

(1) Heating-up and reduction of burden assured throughout the furnace by means of the preheating gas injection.

(2) Appropriate preheating gas, in which the low fuel rate is realized, is the range of preheating gas flow rates corresponding to thermal flow ratio in the upper part of $0.74-0.90$ and the range of temperatures $600-1200^{\circ} \mathrm{C}$.

(3) The preheating gas composition has little influence on the reduction in the lower part.

(4) The position of preheating gas injection is adequate in the upper shaft as long as the heat transfer is secured.

(5) Operational fuel rate range is wide; $500 \mathrm{~kg} / \mathrm{t}$ (with preheating gas) $-1200 \mathrm{~kg} / \mathrm{t}$ (without preheating gas).

KEY WORDS: ironmaking; blast furnace; oxygen; preheating gas injection; pulverized coal; experimental blast furnace; mathematical model; fuel rate; productivity; low shaft furnace.

\section{Introduction}

Recently, greater operational flexibility is required for the blast furnace operation; for example, intensive pulverized coal injection or a higher production rate. However, an advanced improvement in the blast furnace process fulfilling these requirements has not yet been developed. Although several attempts have also been made to develop a new ironmaking process, ${ }^{1,2}$ there is no process which replaces the blast furnace process at present.

The authors have proposed the 'Oxygen Blast Furnace Process'. ${ }^{3-7)}$ The process is based on the blast furnace process and characterized by blowing room temperature oxygen through the tuyeres with a high coal injection rate and by injecting preheating gas into the upper shaft. In the process, the burden is heated up to a temperature above which gaseous reduction proceeds by.injecting preheating gas and high reducing potential of bosh gas generated from the oxygen blast is effectively used. The process was verified through experimental blast furnace operations. ${ }^{3-5)}$ The heating-up and reaction characteristics of the process were also studied using a mathematical model. ${ }^{6)}$

In this paper, the outline of the fundamental concept, the advantages of the process and results of the verification of the process through an experimental blast furnace operation are described. The estimated results of the operating conditions for a commercial oxygen blast furnace, that are the appropriate conditions for the preheating gas injection, productivity, the fuel rate range and the lowering of the furnace height, are also reported.

\section{Outline of Concept and Advantages of the Process}

Durrer $^{8)}$ noted the advantages of the oxygen blast furnace were as follows. The top gas temperature decreased because of the low bosh gas flow rate and therefore thermal efficiency was improved. The reduction rate increased because of the high reducing gas concentration and the furnace height could be lowered. As a result, low grade materials could be used. Following that, a test operation with a high oxygen enriched hot blast was carried out using a low shaft experimental blast furnace in Europe. ${ }^{9}$ However, several operating 
problems, such as the insufficient heating-up and reduction of burden, hanging and channeling arose. As a result, the process could not be sufficiently developed. When the oxygen content is increased in the hot blast operation, the bosh gas flow rate decreases and the thermal flow ratio increases. Therefore, the heating-up of the burden becomes insufficient. Miyashita et al. ${ }^{10)}$ made these phenomena clear using an experimental bast furnace. Few tests have been successfully carried out using oxygen with a concentration of less than $50 \% .{ }^{11-13)}$ These test operations were carried out with a high fuel rate. Therefore, the thermal flow ratio was low, and the thermal shortage in the shaft came not to be a problem. Recently, Wartmann, ${ }^{143} \mathrm{Lu}$ and Kumar, ${ }^{15)}$ Qin and Yang ${ }^{16)}$ and Fink ${ }^{17)}$ have studied the oxygen blast operation. In these studies, as a countermeasure for the thermal shortage in the shaft caused by the high oxygen content blast, the top gas injection into the tuyere or the reducing gas injection at the lower shaft or the bosh level were discussed using material and heat balance models.

Figure 1 shows the fundamental concept and advantages of the proposed oxygen blast furnace process. The basic constitution of the process is that normal temperature oxygen is blown into the tuyeres and the preheating gas is injected into the upper shaft. Hot stoves are not necessary. The intensive pulverized coal injection is possible and the coke rate can be reduced. With the oxygen blast, the bosh gas flow rate is so low that the preheating gas injection into the upper shaft improves the temperature profile in the furnace. The thermal reserve zone temperature $\left(T_{R}\right)$ is determined by the coke reactivity in the conventional blast furnace at about $950-1000^{\circ} \mathrm{C}$. In the process, $T_{R}$ can be controlled by the preheating gas flow rate and temperature, and the operation over a wide range of fuel rates is possible. As the concentration of reducing gas in the bosh gas is high, the gaseous reduction rate is high. Productivity can be increased because of the low bosh gas flow rate. As the heating-up of the burden is similar to that in the hot blast operation by using the preheating gas injection, the direct reduction rate is decreased and the reducing time is shortened. As a result, the furnace height can be lowered and the coke strength can be reduced.

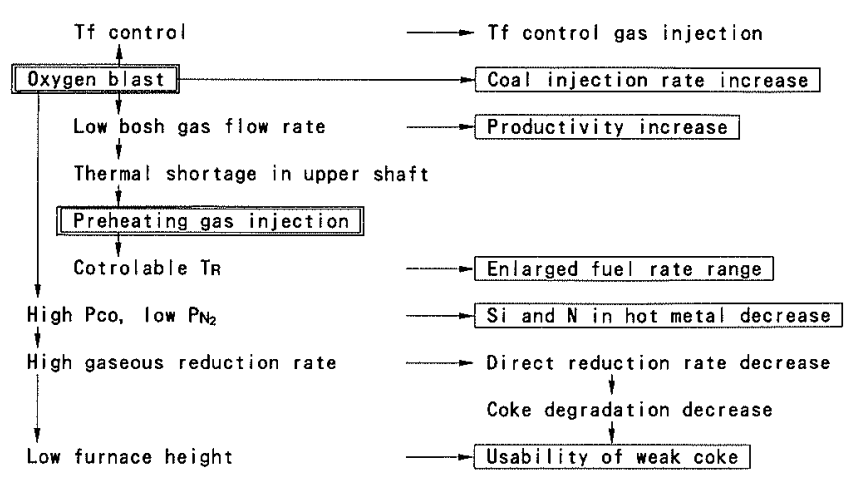

Fig. 1. Concept and advantages of oxygen blast furnace process.

\section{Fundamental Characteristics of the Process}

In order to understand the fundamental characteristics of the process, the operating conditions were studied using a material and heat balance model, and the characteristics of the heating-up and of the reaction progress in the furnace were estimated using a onedimensional mathematical model. The estimated results were partially reported in the previous paper. ${ }^{7)}$

In analysis by means of the material and heat balance model, ${ }^{4)}$ the furnace is divided into two parts-above and below the preheating gas injection level-and the material and heat balances are calculated in each part. According to the estimated results, a thermal shortage in the shaft is avoided through the preheating gas.injection into the upper shaft.

The one-dimensional model is similar to the ones presented by Taguchi et al. ${ }^{18)}$ and Hatano et al. ${ }^{19)}$ According to results estimated by applying the model to the process, the burden is heated up to about $700^{\circ} \mathrm{C}$ at the preheating gas injection level, and once the heating-up of the burden stays below the injection level, and the burden is sufficiently heated before it reaches the tuyere level. The reduction is faster in the lower temperature region compared to the hot blast operation, so the direct reduction rate is smaller.

Figure 2 shows the effect of the preheating gas temperature $\left(T_{H}\right)$ on the thermal reserve zone temperature $\left(T_{R}\right)$ and the direct reduction rate $\left(Y_{d}\right.$ : the number of oxygen atoms that combined with carbon in the direct reduction ${ }^{20)}$ ). In the figure, $V_{H}$ is the preheating gas injection rate, $C R$ the coke rate and PCR the pulverized coal rate. $T_{R}$ is mainly determined by the reactivity of coke in the conventional hot blast operation, but is controlled by $T_{H}$ in the oxygen blast operation. $Y_{d}$ is about 0.5 in the hot blast operations, while it is about $0.1-0.2$ in the oxygen blast operations because of the large gaseous reduction.

From the above analysis, realization and fundamental characteristics of this process could be estimated.

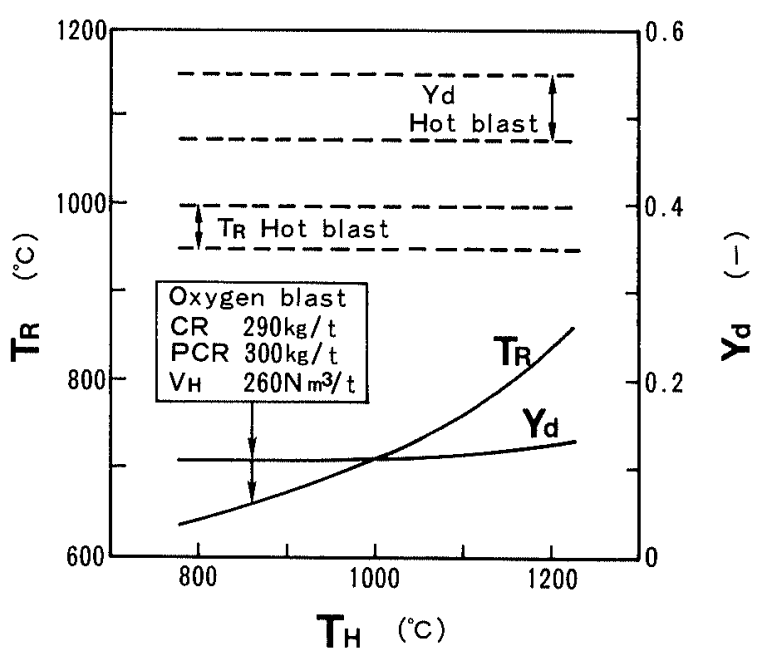

Fig. 2. Effect of preheating gas temperature $\left(T_{H}\right)$ on solid temperature at thermal reserve zone $\left(T_{R}\right)$ and direct reduction rate $\left(Y_{d}\right)$. 
4. Verification of the Realization of the Oxygen Blast Furnace Process through the Experimental Blast Furnace Operations

Experimental blast furnace operations were carried out and the process realization could be verified. The operational and analytical results are described below.

\subsection{Experimental Blast Furnace Equipment}

An outline of the experimental blast furnace is as follows; inner volume $3.9 \mathrm{~m}^{3}$, hearth diameter $0.95 \mathrm{~m}^{\phi}$, throat diameter $0.7 \mathrm{~m}^{\phi}$, distance from throat to tuyere $5.1 \mathrm{~m}$ and to the preheating gas injection level $1.5 \mathrm{~m}$, three blast tuyeres, and three preheating gas tuyeres. The preheating gas was prepared by burning LPG with oxygen and diluting it with $\mathrm{N}_{2}$ or steam. A typical composition of the preheating gas was $\mathrm{CO}=2.2 \%$, $\mathrm{CO}_{2}=7.1 \%, \mathrm{H}_{2}=0.1 \%, \mathrm{H}_{2} \mathrm{O}=9.6 \%$ and $\mathrm{N}_{2}=81 \%$. Both the oxygen blast operation and the hot blast operation were carried out. After the blow-off operation, which was similar to the period III operation in Table 1, the furnace was quenched with nitrogen, and ore samples were taken from a shaft part. The lower part of the furnace was fixed with resin for observation and analysis.

\subsection{Experimental Operation Results and Analysis}

Continuous operations for one and a half months each were carried out. The operations were very stable.
Table 1 shows typical examples of the operating results.

(1) Analysis of Material and Heat Balances

Table 1 and Fig. 3 show the analytical results of the test operation. The necessary heat was almost the same in the hot blast operation (Period I) and the oxygen blast operation (Period II). In Period III, in which pulverized coal was injected at a rate of $320 \mathrm{~kg} / \mathrm{t}$, the necessary heat decreased greatly and the fuel rate also decreased. This is the reason why the steam injection was stopped in order to maintain the theoretical flame temperature $\left(T_{f}\right)$. In Period IV, in which production increased to $20 \mathrm{t} / \mathrm{d}$, although $Y_{d}$ increase compared to the Period III because the residence time of the burden in the furnace decreased, the necessary heat and the fuel rate (FR) decreased because of the decreased heat loss.

Figure 4 shows the relationship between $Y_{d}$ and FR. In both the hot blast and the oxygen blast operation, $Y_{d}$ decreased with the increase in FR. It is considered that the gaseous reduction rate became larger with the increase in the reduction gas flow rate. When FR was $650 \mathrm{~kg} / \mathrm{t}, Y_{d}$ was about 0.45 in the hot blast operation, but in the oxygen blast operation, $Y_{d}$ was low, about 0.2 .

(2) Preheating Gas Injection and Thermal Flow Ratio

Figure 5 shows the relationship between the thermal flow ratio $(U)$ and $\mathrm{FR}$. In calculating $U$, all specific heat

Table 1. Operating results of experimental blast furnace

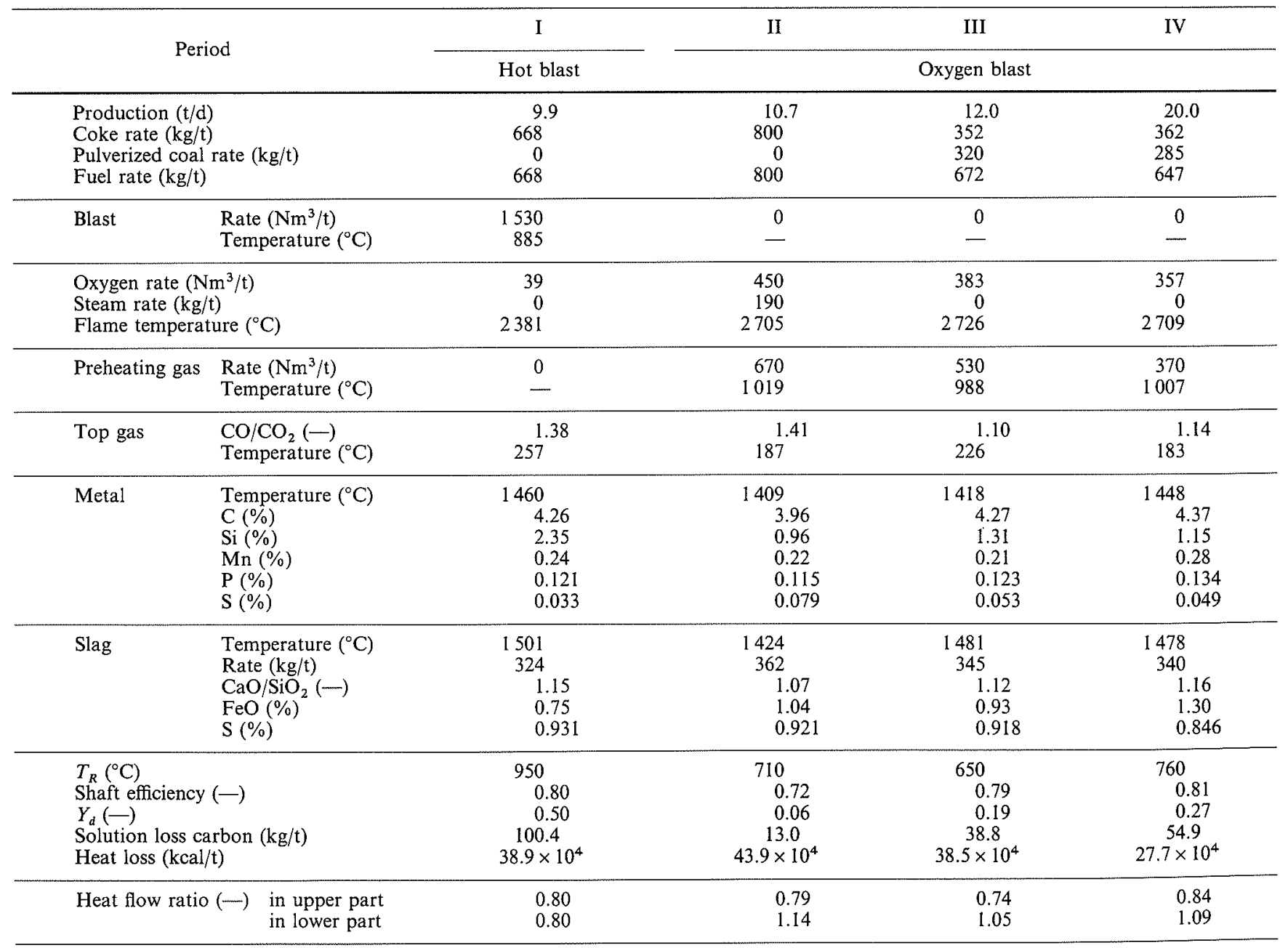




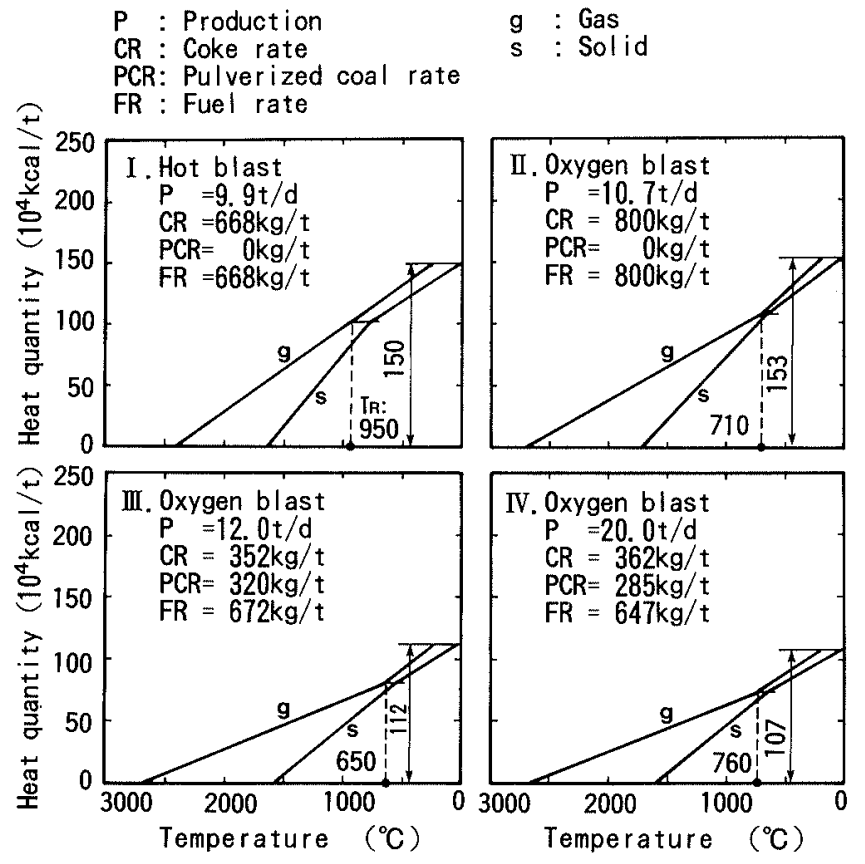

Fig. 3. Reichardt's diagrams for some typical periods of experimental operation.

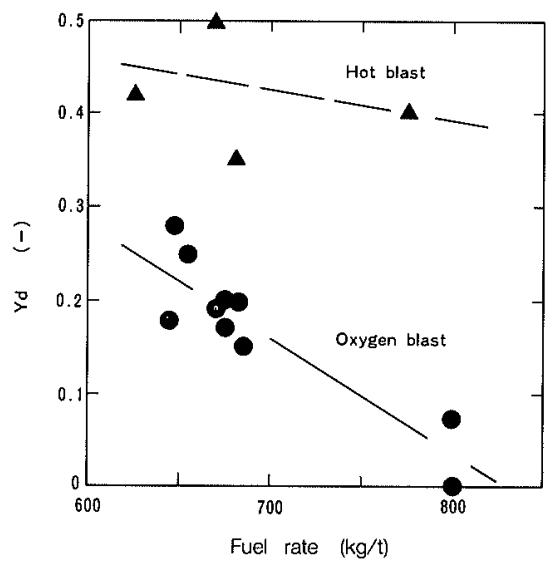

Fig. 4. Relation between direct reduction rate $\left(Y_{d}\right)$ with fuel rate.

values were based on values at $500^{\circ} \mathrm{C}$. The composition and the flow rate of the solid and the gas were based on values at the throat. Only in calculating $U$ in the lower part in the oxygen blast operation, the gas flow rate in the lower part was obtained by subtracting $V_{H}$ from the gas flow rate at the throat. In the oxygen blast operation, $U$ is high in the lower part, while it decreases in the upper part with the injection of the preheating gas to a value similar to that in the hot blast operation. In the oxygen blast operation, when $T_{f}$ is lowered and FR is as high as $900 \mathrm{~kg} / \mathrm{t}$, and as $U$ decreases to about 0.8 , the operation may be possible without the preheating gas injection. As in the data of Okamoto et al. ${ }^{12)}$ and the Bureau of Mines ${ }^{13)}$ shown in Fig. 5, when the oxygen content is low, the limit of $U$ is seen to be lower.

\section{(3) Pulverized Coal Injection Rate}

The increase in PCR was accompanied by the decrease in the steam rate in order to maintain $T_{f}$. Then FR was markedly lowered. In Period III, where PCR was $320 \mathrm{~kg} / \mathrm{t}\left(\mathrm{PC}(\mathrm{kg}) / \mathrm{O}_{2}\left(\mathrm{Nm}^{3}\right)=0.84\right)$. When the

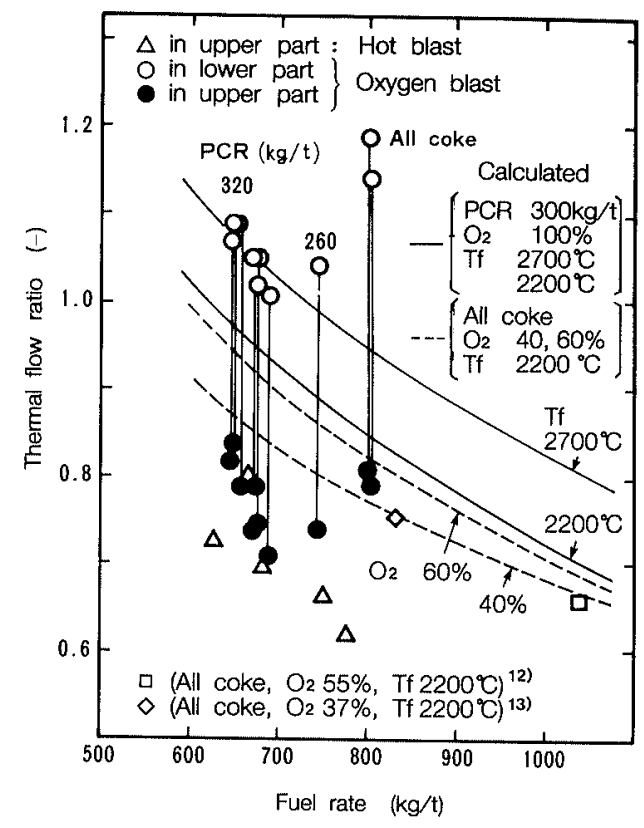

Fig. 5. Relation of thermal flow ratio with fuel rate.

steam was cut off, FR was $672 \mathrm{~kg} / \mathrm{t}$ and $T_{f}$ was about $2700^{\circ} \mathrm{C}$. After Period III, in order to investigate the replacement ratio, PCR was increased and the coke rate (CR) was gradually reduced, while keeping the oxygen flow rate constant. $T_{f}$ decreased with the increase of the $\mathrm{PC} / \mathrm{O}_{2}$ ratio, but the replacement ratio was constant until after $\mathrm{PCR}=363 \mathrm{~kg} / \mathrm{t} \quad\left(\mathrm{PC}(\mathrm{kg}) / \mathrm{O}_{2}\left(\mathrm{Nm}^{3}\right)=0.94\right)$. Above this value, the replacement ratio worsened.

(4) Productivity

In Period IV, it was possible to continue a stable operation up to $20.0 \mathrm{t} / \mathrm{d}$ production (productivity $5.1 \mathrm{t} / \mathrm{m}^{3} / \mathrm{d}$ ). It seemed that the production rate could be increased further, but this was at a maximum due to tapping work restriction.

\section{(5) In-furnace Condition}

From the measured results of the temperature and the gas composition in the furnace, the thermal reserve zone was observed at about $950^{\circ} \mathrm{C}$ in the case of the hot blast operation. When $T_{H}$ was about $1000^{\circ} \mathrm{C}$ and $V_{H}$ was about $500 \mathrm{Nm}^{3} / \mathrm{t}$, in the case of the oxygen blast operation (Period III), the gas temperature at the injecting level was as low as about $700^{\circ} \mathrm{C}$. This almost agrees with the mathematical model estimation. ${ }^{7}$ When $V_{H}$ was increased, the temperature rose in all sections above the injection level. This shows the preheating gas injection has an effect on the whole horizontal section.

Figure 6 shows the temperature distribution and the gas composition in the blow-off operation, and the distribution of the reduction degree of sinter taken after blow-off. Even though the temperature in the lower part of the shaft was less than $800^{\circ} \mathrm{C}$, the reduction degree was rather high-more than $90 \%$. It was confirmed that the gaseous reduction rate was higher in the oxygen blast operations. Figure 7 shows in-furnace situations in the dissected lower part. The ore was completely reduced before melting, and melted down rapidly above the raceway region. A so-called cohesive zone did not exist. It is believed that the softening temperature of the 


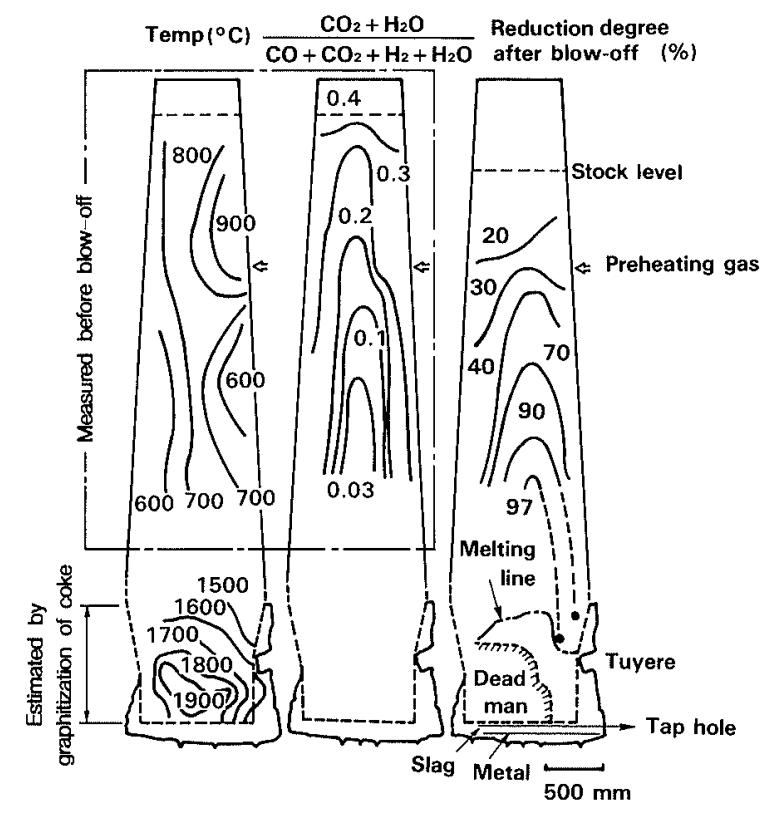

Fig. 6. Distribution of gas temperature, gas composition and reduction degree of sinter.

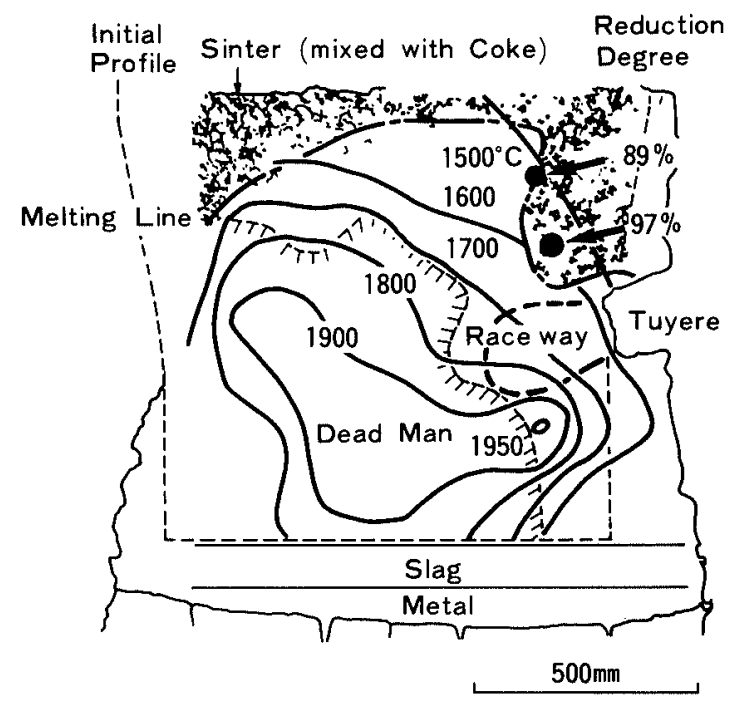

Fig. 7. In-furnace situations and coke temperature distribution in the dissected lower part.

ore rose because of the fast reduction rate. The size and the porosity of coke changed little from the furnace top to the raceway. This corresponds with the low solution loss rate. Gas permeability in the dead man might have been good judging from the temperature distribution measured by the graphitization of coke samples.

\section{Estimation of the Operating Conditions of the Oxygen Blast Furnace on a Commercial Scale}

The significant operating conditions to be investigated for a commercial oxygen blast furnace are as follows; use of preheating gas injection, productivity, fuel rate, and furnace height. These are discussed using oneand two-dimensional mathematical models. The twodimensional model is similar to the one presented by Kuwabara et al. ${ }^{21)}$ The model is an axially symmetric steady-state model which considers the simultaneous process of the burden flow, gas flow, heat transfer, mass transfer and chemical reactions. The applicability of
Table 2. Base condition of simulations.

$\begin{array}{lc}\text { Coke rate } C R(\mathrm{~kg} / \mathrm{t}) & 250 \\ \text { Pulverized coal rate } P C R(\mathrm{~kg} / \mathrm{t}) & 300 \\ \text { Fuel rate }(\mathrm{kg} / \mathrm{t}) & 550 \\ \text { Flame temperature } T_{f}\left({ }^{\circ} \mathrm{C}\right) & 2600 \\ \text { Blast rate }\left(\mathrm{Nm}^{3} / \mathrm{t}\right) & 292 \\ \text { Oxygen in blast }(\%) & 99.5 \\ T_{f} \text { control gas } \text { species } & \text { Top gas } \\ \text { rate }\left(\mathrm{Nm}^{3} / \mathrm{t}\right) & 46 \\ \text { Bosh gas rate }\left(\mathrm{Nm}^{3} / \mathrm{t}\right) & 865 \\ \text { temperature }\left({ }^{\circ} \mathrm{C}\right) & 2100 \\ \mathrm{CO}(\%) & 81.7 \\ \mathrm{H}_{2}(\%) & 17.5 \\ \mathrm{~N}_{2}(\%) & 0.8 \\ \text { Preheating gas rate } V_{H}\left(\mathrm{Nm}^{3} / \mathrm{t}\right) & 300 \\ \text { temperature } T_{H}\left({ }^{\circ} \mathrm{C}\right) & 1000 \\ \text { oxidation degree } \eta_{H}(-) & 0.72 \\ \text { injection level } Z_{H}(\mathrm{~m}) & 7.5\end{array}$

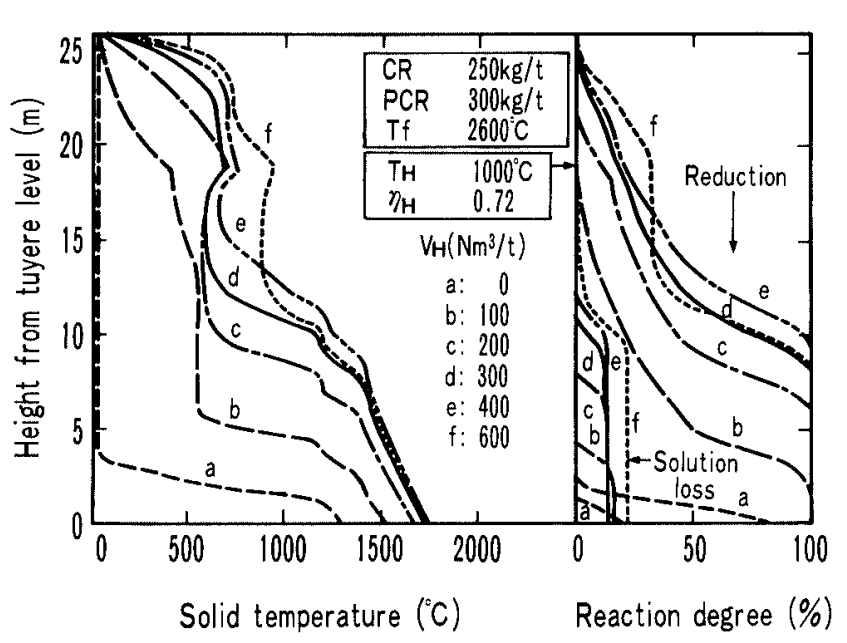

Fig. 8. Effect of preheating gas flow rate $\left(V_{H}\right)$ on longitudinal distribution of solid temperature and reaction degree.

these models has been reported in the other papers. ${ }^{6,22)}$ Based on the typical operating condition of the oxygen blast furnace as shown in Table $2{ }^{6}{ }^{6}$ some operating variables are estimated. The blast furnace applied is NKK's Fukuyama No. 4 blast furnace (inner volume; $\left.4288 \mathrm{~m}^{3}\right)$.

\subsection{Appropriate Conditions for the Preheating Gas Injection}

In order to investigate the appropriate conditions for the preheating gas injection in the shaft, the injected gas rate $\left(V_{H}\right)$, temperature $\left(T_{H}\right)$, composition and the position of injection were varied, and the heating-up and the reduction progress were analyzed.

(1) Rate and Temperature

Figure 8 shows the calculated results using a onedimensional model with varied $V_{H}$. As $V_{H}$ increases, $U$ in the upper part decreases, and the solid temperature raises throughout the furnace. Therefore the reduction is accelerated. As a result, $Y_{d}$ decreases and the solid temperature at the tuyere level $\left(T_{s t}\right)$ increases. Although the rate of heating-up in the shaft increases when $V_{H}$ is $600 \mathrm{Nm}^{3} / \mathrm{t}$, the reduction ability of gas decreases at the same time because of the decrease in the oxidation degree of the $\mathrm{FeO}-\mathrm{Fe}$ equilibrium gas composition. Therefore, the reduction slows down, $Y_{d}$ increases, and 


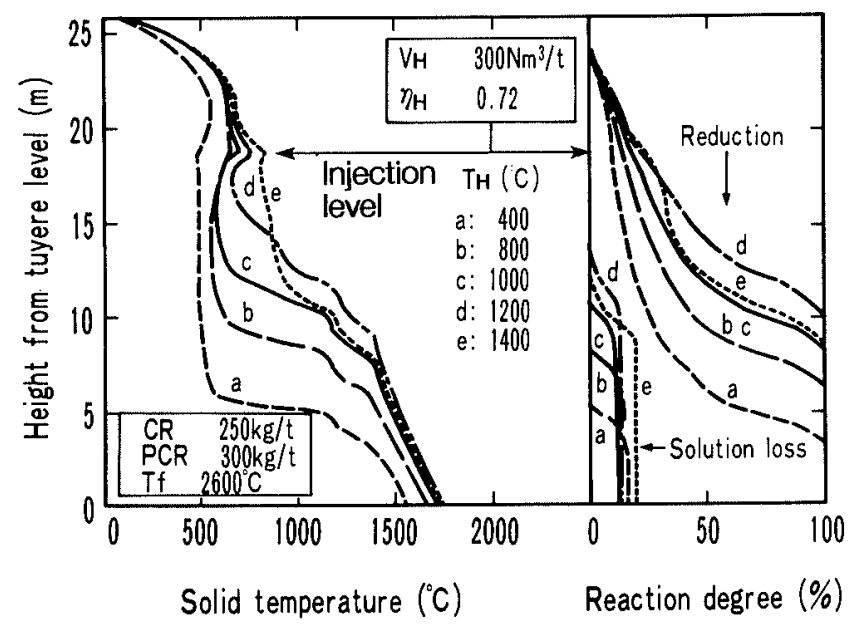

Fig. 9. Effect of preheating gas temperature $\left(T_{H}\right)$ on longitudinal distribution of solid temperature and reaction degree.

Preheating gas rate: $300 \mathrm{Nm}^{3} / \mathrm{t}$ ....... 90\% reduction degree

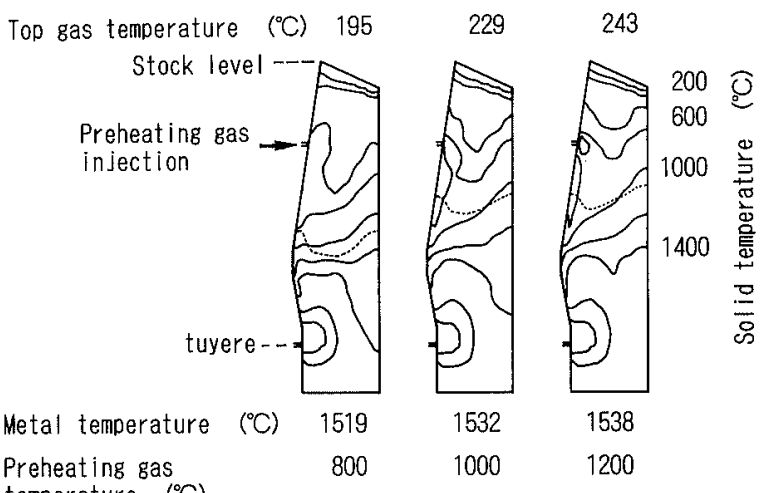

Preheating gas

temperature $\left({ }^{\circ} \mathrm{C}\right)$

Fig. 10. Effect of preheating gas temperature $\left(T_{H}\right)$ on solid temperature and reduction degree distribution in the furnace.

$T_{s t}$ becomes almost constant. From the simulated results using the two-dimensional model, as an example is shown in Fig. 13, the preheating gas injected in the shaft flows in the vicinity of the furnace wall. Therefore the gas from the lower part flows in the direction of the furnace center. As a result, the heating-up of burden is secured throughout the upper shaft.

Figure 9 shows the calculated results using a onedimensional model with varied $T_{H}$. When the temperature is below $1000^{\circ} \mathrm{C}$, the heating-up and the reduction are delayed throughout the furance. Conversely, when $T_{H}$ rises, the temperature near the injection level rises and the reduction is accelerated. However, when $T_{H}$ raises to $1400^{\circ} \mathrm{C}$, the reduction slows down and $Y_{d}$ increases because of the restriction in the reduction equilibrium. Since the increase in the heat content of solid descending into the lower part counterbalances the heat required for the increased direct reduction, there is almost no change in the temperature distribution in the lower part. This tendency is also seen in the changes of $V_{H}$. Figure 10 shows the temperature distribution and the position of $90 \%$ reduction degree in the furnace with the two-dimensional model. When the temperature of injection gas of $300 \mathrm{Nm}^{3} / \mathrm{t}$ is varied in the range

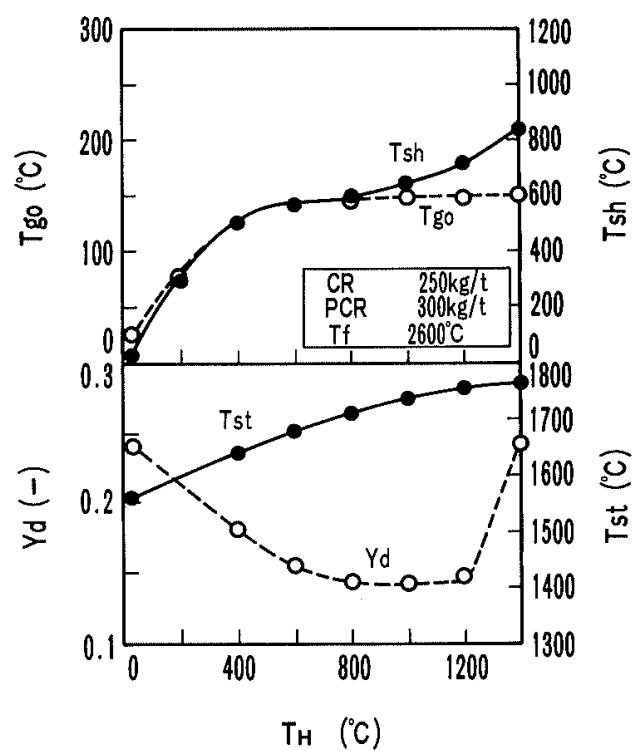

Fig. 11. Effect of preheating gas temperature $\left(T_{H}\right)$ on top gas temperature $\left(T_{g o}\right)$, solid temperature at preheating gas injection level $\left(T_{s h}\right)$, direct reduction rate $\left(Y_{d}\right)$ and solid temperature at tuyere level $\left(T_{s t}\right)$.

of $800-1200^{\circ} \mathrm{C}$, the heating-up and the reduction accelerate in both the upper and lower part, and the hot metal temperature also rises. However, when $T_{H}$ is varied from 1000 to $1200^{\circ} \mathrm{C}$, there is a small heating-up in the upper shaft, but there is almost no effect on the heating-up at levels above $1000^{\circ} \mathrm{C}$, and there is no acceleration in the reduction rate in the lower part. These simulated results with one- and two-dimensional models show good agreement. This agreement found in the simulated results using the different models indicates that these estimations are considered to be reliable.

Figure 11 shows the effects of $T_{H}$ on the top gas temperature $\left(T_{g o}\right)$, the solid temperature at the preheating gas injection level $\left(T_{s h}\right), T_{s t}$ and $Y_{d}$. Although $T_{g o}$ rises together with a rise in $T_{H}, T_{g o}$ is constant at temperatures over $T_{H}=600^{\circ} \mathrm{C}$. Changes in $T_{s h}, T_{s t}$ and $Y_{d}$ in Fig. 11 are similar to the changes in $V_{H}$.

As mentioned-above, there is a range of $V_{H}$ and $T_{H}$ in which $Y_{d}$ is minimum. The gaseous reduction advances at temperatures over about $500^{\circ} \mathrm{C}$, and the solution loss reaction at temperatures over about $1000^{\circ} \mathrm{C}$. On the other hand, the heating-up of burdens is decided by $U$ and $T_{H}$. When the residence time of burden between $500-1000^{\circ} \mathrm{C}$ is sufficiently long enough and the reduction of ore is not restricted by the reduction equilibrium, the gaseous reduction advances preferentially. As a result, the reduction degree is sufficient before ore reaches a temperature at which the solution loss reaction proceeds, so $Y_{d}$ reduces and $T_{s t}$ rises. The appropriate values of $V_{H}$ and $T_{H}$, in which $Y_{d}$ and FR are low, are in the range corresponding to 0.74 0.90 of $U$ in the upper shaft and at temperatures of $600-1200^{\circ} \mathrm{C}$. This wide appropriate range indicates that this process can be operated stably at the low fuel rate.

\section{(2) Composition}

Figure 12 shows the calculated results when the preheating gas composition is varied. When the preheating 
gas composition is reducible (oxidation degree $\eta_{H}=0$ ), the reduction rate is accelerated in the upper shaft, but the effect is not so large throughout the whole furnace. In this process, the position of the preheating gas injection is located in the upper part of the furnace, and the role of the gas injection is to heat the burden up to not so high a temperature in which only the gaseous reduction is accelerated and the solution loss reaction is not accelerated. Because, in addition to these situations, the reducing gas concentration in bosh gas is high, the effect of the preheating gas composition is considered to be small.

\section{(3) Position of Injection}

Penetration of the gas injected into blast furnace stack is proportional to the ratio of injected gas to the total amount of inner gas, and influenced by the radial eddy diffusion of the gas and the radial distribution of burden. ${ }^{23)}$ Several processes which injected the reducing gas into the blast furnace stack were presented in the hot blast furnace process. ${ }^{24,25)}$ From the viewpoint of the penetration and the utilization of the reducing gas for the reduction of ore in the process, it was reported that the gas should contain less $\mathrm{CO}_{2}$ and $\mathrm{H}_{2} \mathrm{O}$ and had to be heated above $1000^{\circ} \mathrm{C}$ and should be injected at below the thermal reserve zone. ${ }^{26)}$ However, the role of the gas injection in the proposed oxygen blast furnace process is to heat up the burden, as mentioned in the previous section.

Figure 13 shows the gas stream line and the distribu-

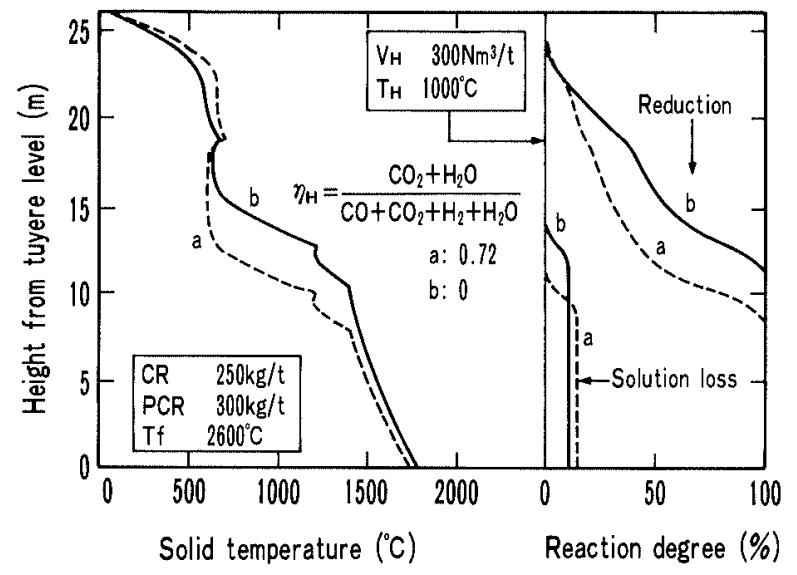

Fig. 12. Effect of preheating gas composition on longitudinal distribution of solid temperature and reaction degree. tion of burden temperature and $90 \%$-reduction degree when the position of the preheating gas injection is varied from the upper part to the lower part of the shaft. From the aspect of the gas stream line, the lower the injection level, the larger the penetration region of the injected gas in the furnace. However, from the viewpoint of heating-up, when gas is injected into the shaft at the distance, $3 \mathrm{~m}$, from the stock level, since the heat exchanging distance is short, the heat of injected gas is not sufficiently transferred to the burden, and $T_{g o}$ rises. When gas is injected at $9 \mathrm{~m}$, the heat of injected gas is effectively utilized, and the heating-up of burden in the upper part adequately promotes the reduction of ore in the lower part. When gas is injected at $16 \mathrm{~m}$, it results in a cooling down of the injected area becáuse of an increase in the quantity of solution loss compared to the injection at $9 \mathrm{~m}$. From these estimations, there is an optimum position of preheating gas injection, which is considered to be the upper part of the shaft as long as the sufficient heat transfer is secured.

\subsection{Productivity}

In this process, the bosh gas flow rate is low compared to that of a hot blast furnace. Therefore, the flooding in the lower part of the furnace is not the significant factor in the restriction of productivity. Maximum productivity in the process may be determined by the reduction of ore, the heating-up of burden and the channeling of gas at the stock level. Simulations of the oxygen blast operation and the hot blast one have been carried out using a one-dimensional model, and varying the productivity. Figure 14 shows the results. In the figure, the position is shown, where a reduction degree of $90 \%$ and a solid temperature of $1400^{\circ} \mathrm{C}$ are achieved. In these cases, the heating-up of burden and the reduction of ore are almost completed at a distance, $4 \mathrm{~m}$, from the tuyere level. From these results, the factor which determines the maximum productivity is the channeling limit. In the case of oxygen blast operations, the maximum productivity is estimated at $3.8 \mathrm{t} / \mathrm{m}^{3} / \mathrm{d}$, which is much higher than the value of 2.6 in hot blast ones. This is because the gas flow rate is lowered in oxygen blast operations. In the oxygen blast operation with a maximum productivity of $3.8 \mathrm{t} / \mathrm{m}^{3} / \mathrm{d}$, the reduction and the heating-up is the same as those in hot blast operations with a usual productivity of $2.0 \mathrm{t} / \mathrm{m}^{3} / \mathrm{d}$.
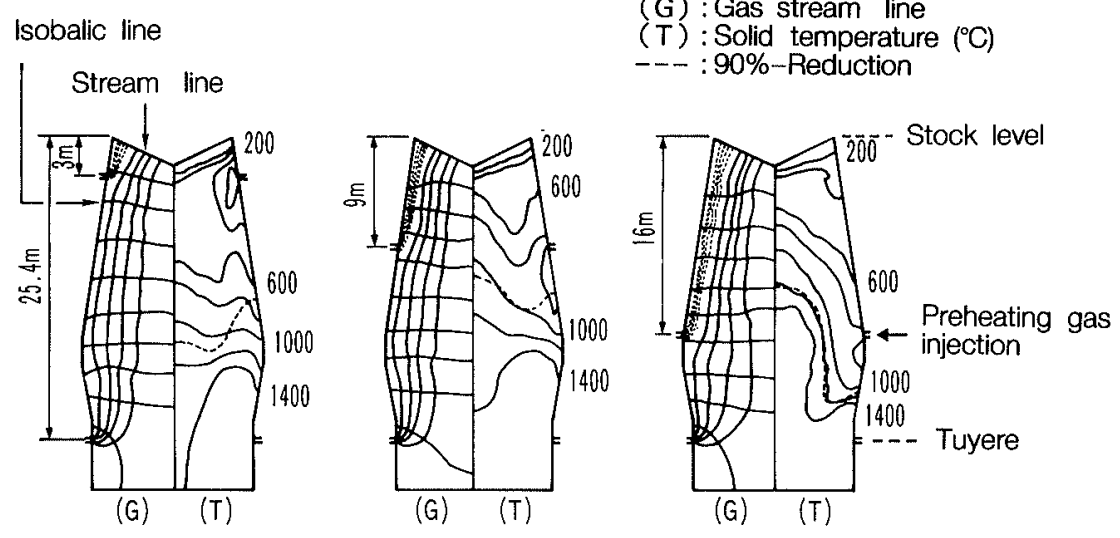

(G) : Gas stream line ( T) : Solid temperature $\left({ }^{\circ} \mathrm{C}\right)$ - - : $90 \%$-Reduction
Fig. 13.

Effect of preheating gas injection level on the distribution of gas flow, solid temperature and reduction 


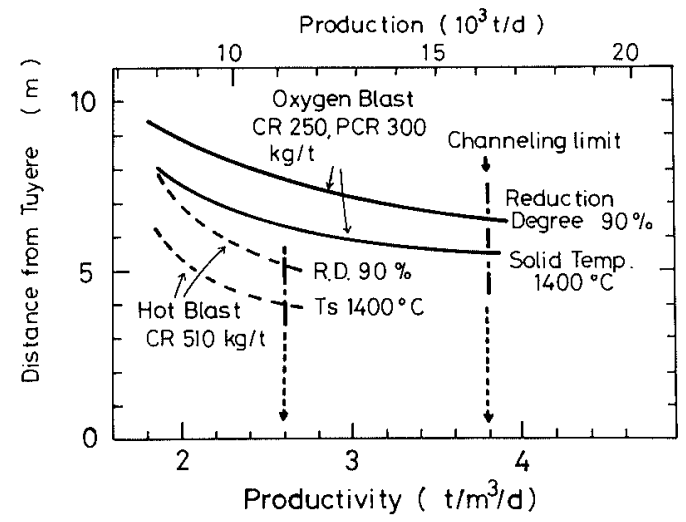

Fig. 14. Comparison of productivity of oxygen blast furnace and hot blast furnace estimated for Fukuyama No. 4 BF $\left(4288 \mathrm{~m}^{3}\right)$

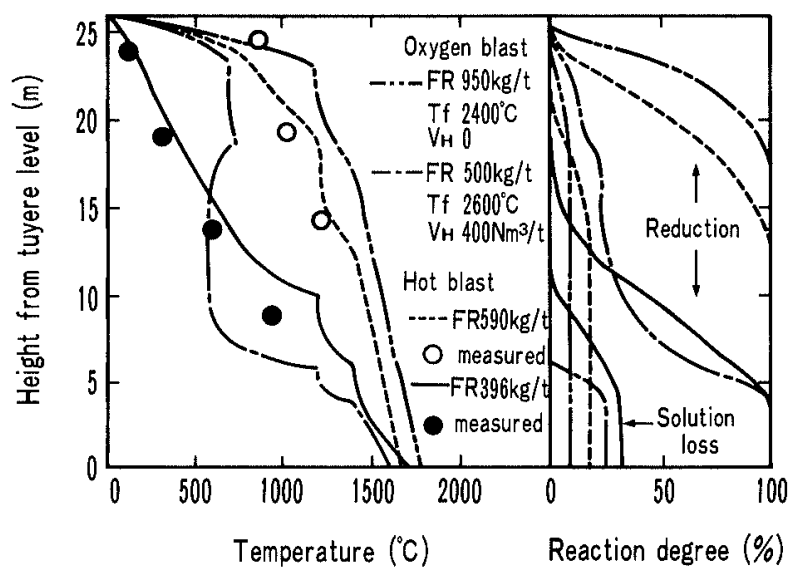

Fig. 15. Comparison of longitudinal distribution of solid temperature and reaction degree at upper and lower limit of fuel rate between oxygen blast operation and hot blast operation.

\subsection{Fuel Rate Range}

In regard to the fuel rate range from the kinematic viewpoint, the lower limit is determined by that which is not able to maintain the hot metal temperature due to insufficient heating-up and reduction. The upper limit is determined by that which raises excessively the hot metal and the top gas temperature. In the reported fuel rates of the hot blast operation in the commercial blast furnaces, the lowest was $396 \mathrm{~kg} / \mathrm{t}^{27)}$ and the highest was $590 \mathrm{~kg} / \mathrm{t},{ }^{28)}$ in an ordinary operation, which used agglomerated ore and produced pig iron for steelmaking. The lowest one operated in the high $T_{f}$ and the liquid fuel injection. The highest one operated in the low $T_{f}$ and the all coke operation with the steam injection. The simulated results of these two limiting operations using the one-dimensional model are shown in Fig. 15. From these results, in the case of the lowest fuel rate operation $396 \mathrm{~kg} / \mathrm{t}, U$ is 0.91 , the shaft efficiency $(R) 0.92$, and $Y_{d} 0.49$. Therefore it can be understood that the heating-up and the reduction were in the limiting state. In the case of the highest fuel rate operation $590 \mathrm{~kg} / \mathrm{t}, T_{g o}$ is very high, at $280^{\circ} \mathrm{C}$.

In the case of the oxygen blast operations, the fuel rate range was estimated with the constant PCR, $300 \mathrm{~kg} / \mathrm{t}$, using the one-dimensional model. The lower limit was analyzed with the preheating gas injection

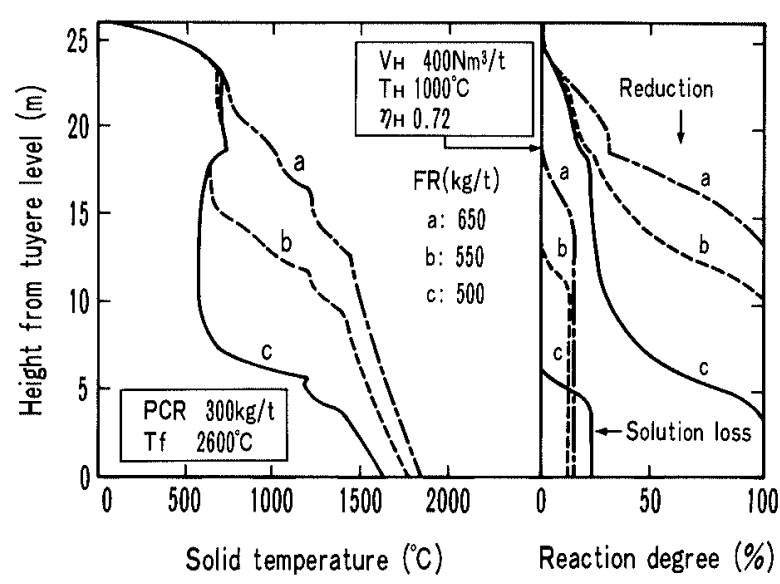

Fig. 16. Transition of longitudinal distribution of solid temperature and reaction degree in decreasing fuel rate with preheating gas.

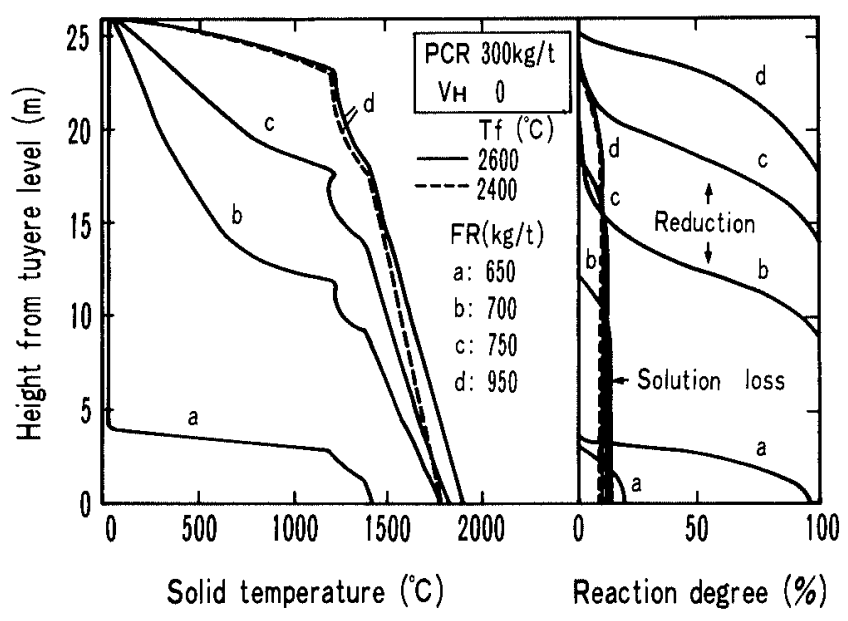

Fig. 17. Transition of longitudinal distribution of solid temperature and reaction degree in increasing fuel rate without preheating gas.

(Series B) and the upper limit without the preheating gas injection (Series C). The calculated results of Series $B$ are shown in Fig. 16. As CR decreases, the heating-up and the reduction slow down. Particularly, when FR is $500 \mathrm{~kg} / \mathrm{t}$, the reduction rate is considerably slower in the middle level of the furnace and the solution loss increases. The calculated results of Series $C$ are shown in Fig. 17, when CR varies from 350 to $650 \mathrm{~kg} / \mathrm{t}$. In the case of FR of $650 \mathrm{~kg} / \mathrm{t}$, the heating-up and the reduction are insufficient. However, in the case of FR over $700 \mathrm{~kg} / \mathrm{t}$, the heating-up and the reduction rate advance well. Figure 18 shows $T_{g o}, U$ and the solid temperature $\left(T_{w}\right)$ at a level where the oxidation degree of ore corresponds to that of wustite $1.05, R, T_{s t}$ and $Y_{d}$ obtained from the calculated results shown in Figs. 16 and 17. In the case of Series B with the preheating gas injection, when $\mathrm{FR}$ is reduced from 550 to $500 \mathrm{~kg} / \mathrm{t}, U$ changes little from 0.73 to 0.75 and the heating-up above the injection level is almost same. But in the lower part, the heating-up and the gaseous reduction are slowed down. Although $T_{w}$ is as low as $570^{\circ} \mathrm{C}$ and the oxidation degree of the $\mathrm{FeO}-\mathrm{Fe}$ equilibrium reducing gas composition is more on the oxidation side, $R$ is close to unity and the gaseous reduction attains the kinematic limit. Consequently, the gaseous reduction is 


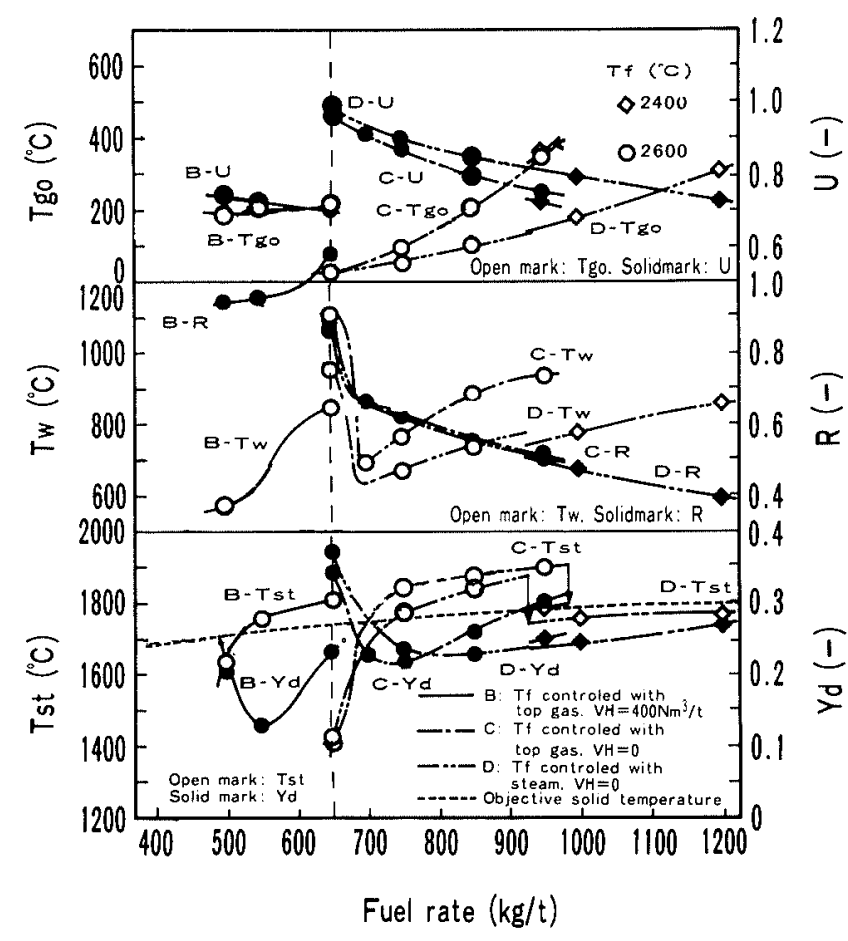

Fig. 18. Effect of fuel rate on thermal flow ratio $(U)$, top gas temperature $\left(T_{g o}\right), \mathrm{FeO}-\mathrm{Fe}$ equilibrium temperature $\left(T_{w}\right)$, shaft efficiency $(R)$, direct reduction rate $\left(Y_{d}\right)$ and solid temperature at tuyere level $\left(T_{s t}\right)$.

retarded, $Y_{d}$ increases and $T_{s t}$ lowers considerably.

On the other hand, in the case of Series C, which is without the preheating gas injection, $Y_{d}$ has a minimum value at about $750 \mathrm{~kg} / \mathrm{t}$ fuel rate. Below this fuel rate, $U$ increases and the gaseous reduction is slowed down because of the heating-up delay, so $Y_{d}$ increases rapidly. At higher fuel rates, the heating-up is higher than the gaseous reduction progress, so $Y_{d}$ increases and $T_{s t}$ is superheated compared to objective temperatures. When $T_{f}$ is lowered from 2600 to $2400^{\circ} \mathrm{C}$, the changes in the upper part are small, as shown in Fig. 17, but temperatures in the lower part decrease and $T_{s t}$ lowers near the objective value. As seen from these results, $T_{s t}$ can be controlled by $T_{f}$.

In-furnace distributions of the calculated results of these lower and upper fuel rate limits of the oxygen blast operation are also shown in Fig. 15 as compared to the hot blast ones. The temperature and the reaction distributions in the range above $1200^{\circ} \mathrm{C}$, in which the softening and the cohesiveness of ore begin, are similar to each other. Therefore, the operations in these fuel rate ranges of the oxygen blast furnace are considered to be possible from the viewpoint of in-furnace conditions.

In regard to $T_{f}, T_{f}$ is controlled in the range of $2000-2400^{\circ} \mathrm{C}$ in the conventional hot blast. operations. High $T_{f}$ can be achieved in the oxygen blast operation compared to the hot blast one. However, the upper limit of $T_{f}$ is not clear in the blast furnace operation. One of the problems in high $T_{f}$ operation is the increase of the vaporized substance and the irregular burden descent caused by the condensation of the vaporized substance. The amount of the vaporized substance in the proposed

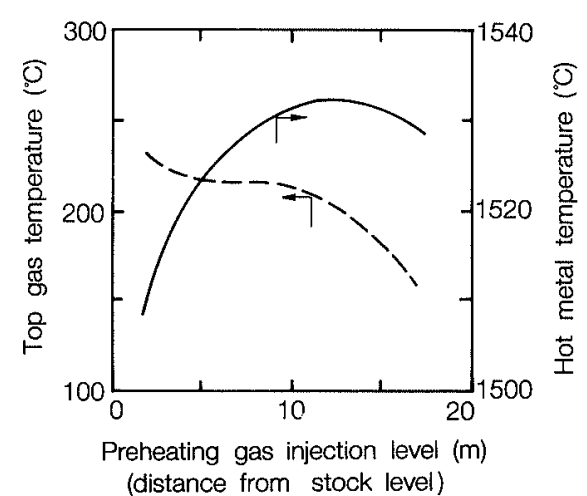

Fig. 19. Effect of preheating gas injection level on top gas and hot metal temperature.

oxygen blast furnace process is lower than that of the hot blast one because the bosh gas flow rate is lower. Therefore, the influence of the condensation of the vaporized substance on the burden decent is considered small compared to the hot blast operation. From these considerations and on referring to the high $T_{f}, 2533^{\circ} \mathrm{C}$, operation, ${ }^{27)} T_{f}$ of $2600^{\circ} \mathrm{C}$ is adopted in the base condition of simulations as shown in Table 2. In the low $T_{f}$ operation, although it is a problem to maintain the hot metal temperature, this can be controlled by FR. From these considerations, it is considered that there is no problem in the operation in which $T_{f}$ range of $2000-2400^{\circ} \mathrm{C}$. However, no matter whether $T_{f}$ is high or low, when the mixing of oxygen, pulverized coal and control gas is insufficient, the extreme temperature increase takes place locally in the raceway. Therefore, the mixing of oxygen, pulverized coal and control gas is important.

In the oxygen blast furnace operation where PCR $=$ $300 \mathrm{~kg} / \mathrm{t}$, the lower limit of FR is estimated to be about $500 \mathrm{~kg} / \mathrm{t}$ from the simulation results of Series B. The upper limit of FR, when the upper limit of $T_{g o}$ is assumed $300^{\circ} \mathrm{C}$ in the same manner as the hot blast operation, is estimated to be about $900 \mathrm{~kg} / \mathrm{t}$ in the case when $T_{f}$ is controlled by circulating the top gas from Series $C$, and about $1200 \mathrm{~kg} / \mathrm{t}$ when it is controlled by the steam from Series D as in Fig. 18.

\subsection{Possibility of Lowering the Furnace Height}

In the oxygen blast furnace process, it is thought that the furnace height can be lowered compared to the hot blast one. Figure 19 shows the calculated results of the changes of top gas and hot metal temperature using the two-dimensional model when the preheating gas injection level is varied. From the figure, when the injection level is varied in the range of 6-12 $\mathrm{m}$ from the stock level, top gas and hot metal temperature changes are not so large. This indicates that the furnace height can be lowered within the range of this height. Figure 20 shows the simulation results when the furnace height and the preheating gas injection condition are varied. In the figure, $\mathrm{A}$ is the base condition. $\mathrm{B}$ is the calculated result when the shaft height is lowered $2.5 \mathrm{~m}$ from $A$. In the case of $B$, the region of $1200-1400^{\circ} \mathrm{C}$ ascends. When the shaft height is decreased more, as in the case of $\mathrm{C}$, temperature is lowered throughout the furnace. In 


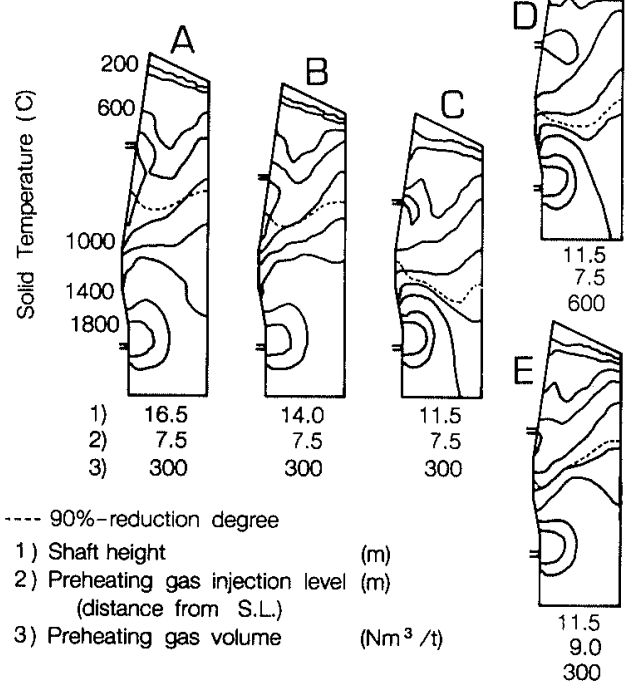

Fig. 20. Calculated result of change of solid temperature and reduction degree distribution with changes of furnace height and condition of preheating gas injection.

order to improve temperature decrease, the increase of $V_{H}$ is not effective (D). Case $\mathrm{E}$ is the calculated results when the injection level was lowered $1.5 \mathrm{~m}$ more than that of $\mathrm{C}$. In this case, the temperature distribution improved remarkably. In the simulation, it is seen that the furnace height is able to be reduced by about $5 \mathrm{~m}$. From these calculations, if the throat diameter is expanded, it is possible to increase productivity further, because it is determined from the channeling limit estimated in Fig. 14.

\section{Conclusion}

In regard to the oxygen blast furnace process which is characterized by the injection of preheating gas into the shaft, operation tests using an experimental blast furnace were carried out to verify this process as being applicable to an ironmaking process. Mathematical model simulations also were carried out to understand the process characteristics on a commercial scale.

The following conclusions were obtained:

(1) From the experimental oxygen blast furnace operation, it was verified as characteristics that the gaseous reduction proceeded fast in a relatively low temperature region and the solution loss reaction rate was low compared to that in the hot blast operation. The pulverized coal was injected up to the ratio of $0.94 \mathrm{~kg}$-coal $/ \mathrm{Nm}^{3}$-oxygen, and the high productivity of $5.1 \mathrm{t} / \mathrm{m}^{3} / \mathrm{d}$ was realized in the test operation. The test operation was so stable that this process was technically verified to be very suitable as an ironmaking process.

(2) The preheating gas injected into the upper shaft flowed in the vicinity of the furnace wall and the gas from the lower part mainly flowed in the furnace center. As a result, the heating-up of burden was secured throughout the upper shaft, and the reduction progress in the lower part was also secured at a high degree.

(3) Appropriate preheating gas, in which the low fuel rate is realized, was estimated to be in the range corresponding to the thermal flow ratio of $0.74-0.90$ in the upper shaft and the temperatures of $600-1200^{\circ} \mathrm{C}$.

(4) The effect of the preheating gas composition on the reduction in the lower part was small.

(5) The position of preheating gas injection was adequate in the upper shaft as long as the heat transfer was secured.

(6) A substantial increase in maximum productivity could be achieved compared to that in the hot blast furnace process.

(7) It was estimated that the range of the fuel rate was wide, and the lower limit and the upper limit of the fuel rate were 500 and $1200 \mathrm{~kg} / \mathrm{t}$, respectively.

(8) It was indicated that this process could be operated with a lower furnace height compared to the hot blast furnace.

\section{REFERENCES}

I) R. B. Smith and M. J. Corbett: Ironmaking Steelmaking, 14 (1987), 49.

2) K. Shiohara: Proc. Second European Ironmaking Cong., The Inst. Met., London, (1991), 310.

3) Y. Ohno, H. Hotta, M. Matsuura, H. Mitsufuji and H. Saito: Process Technology Conf. Proc., AIME, Penn., (1988), 195.

4) Y. Ohno, H. Hotta, M. Matsuura, H. Mitsufuji and H. Saito: Tetsu-to-Hagané, 75 (1989), 1278.

5) H. Mitsufuji, M. Matsuura, T. Furukawa and Y. Ohno: Rev. Metall., (1989), Mars, 217

6) Y. Ohno and M. Matsuura: Tetsu-to-Hagané, 76 (1990), 1262.

7) M. Matsuura, H. Mitsufuji, T. Furukawa and Y. Ohno: Proc. The Sixth International Iron and Steel Cong., Vol. 2, ISIJ, Tokyo, (1990), 581.

8) R. Durrer: J. Iron Steel Inst., 156 (1947), June, 253.

9) Int. Res. Comm. on Low Shaft Furnace: J. Iron Steel Inst., 179 (1955), Jan., 36.

10) T. Miyashita, H. Nishio, T. Shimotsuma, T. Yamada and M. Ohtsuki: Trans. Iron Steel Inst. Jpn., 13 (1973), 1.

11) B. M. Suslov: Iron Age, 134 (1934), No. 4, 1.

12) T. Okamoto, T. Tada and S. Sugiura: Tetsu-to-Hagané, 58 (1972), 637.

13) P. L. Woolf: Bureau of Mines Report, (1985), OFR, 99-85.

14) R. Wartmann: Proc. Fifth Japan and Germany Seminar, VDEh, Düsseldorf, (1982), 133.

15) W-K. Lu and R. V. Kumar: ISS Trans., 5 (1984), 25.

16) Q. Minsheng and Y. Naifu: Scan. J. Met., 15 (1986), 138.

17) F. Fink: Proc. European Ironmaking Cong., VDEh, Düsseldorf, (1986), PV-3.

18) S. Taguchi, H. Kubo, N. Tsuchiya, K. Ichifuji and K. Okabe: Tetsu-to-Hagané, 68 (1982), 2303.

19) M. Hatano, K. Kurita, H. Yamaoka and T. Yokoi: Tetsu-toHagané, 68 (1982), 2369.

20) A. Rist and N. Meysson: J. Met., (1967), April, 50.

21) M. Kuwabara, K. Isobe, K. Mio, K. Nakanishi and I. Muchi: Proc. 2nd Japan-Australia Symp., ISIJ, Tokyo, (1983), 193.

22) M. Matsuura, T. Furukawa, Y. Ohno and Y. Yamaoka: Rev. Metall., (1991), Mai, 453.

23) H. Nishio and T. Miyashita: Tetsu-to-Hagané, 59 (1973), 1506.

24) T. Yatsuzuka, K. Nakayama, K. Omori, Y. Hara and M. Iguchi: Trans. Iron Steel Inst. Jpn., 13 (1973), 115.

25) T. Miyashita, K. Sano, H. Nishio, S. Ohzeki, T. Nayuki and L. Chaussy: Trans. Iron Steel Inst. Jpn., 14 (1974), 176.

26) T. Miyashita, H. Nishio, T. Shimotsuma, T. Yamada and M. Ohtsuki: Tetsu-to-Hagané, 58 (1972), 608.

27) S. Kajikawa, R. Yamamoto, R. Nakajima, S. Kishimoto and T. Fukushima: Tetsu-to-Hagané, 68 (1982), 2361.

28) R. Yamamoto, R. Nakajima, T. Sumigama, A. Maki, K. Wakimoto, Y. Yamada and K. Tomioka: Tetsu-to-Hagané, 72 (1986), S72. 